
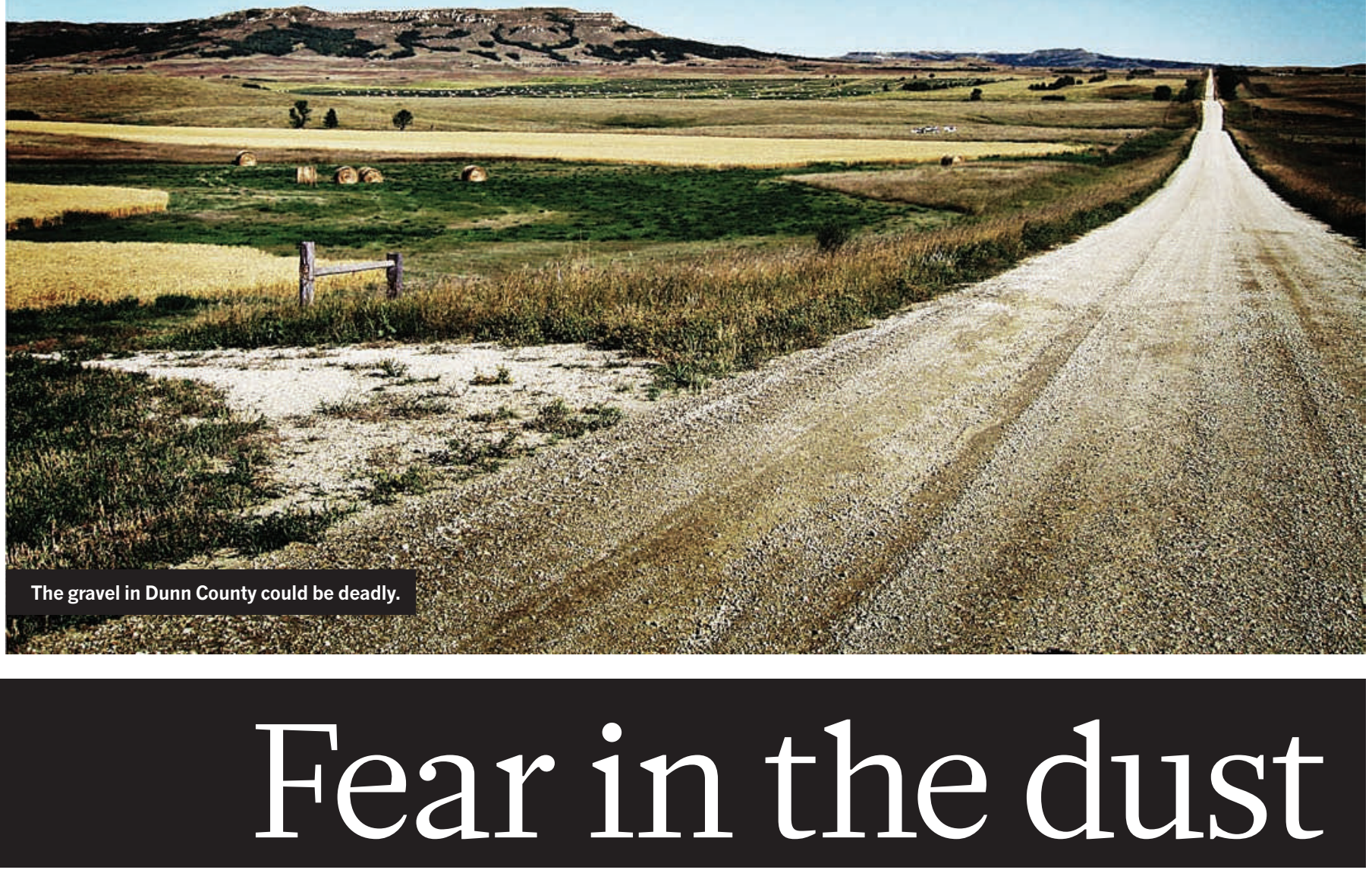

By Brendan Maher

\section{Cancer epidemics in Turkey could hold the secret to staving off a public health disaster in North Dakota.}

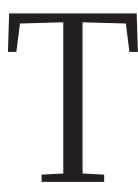

hey became known as the cancer villages - tiny hamlets in Cappadocia, Turkey, that for generations have been haunted by an extremely rare lung condition. Mesothelioma, responsible for up to half of the deaths in these towns, is almost always associated with exposure to asbestos. But here, researchers found a different cause: a mineral called erionite, which is built into the very fabric of the villages. It is on the roads, in the fields and in the stone used to construct the houses.

Now, decades of research in Turkey may help to save lives 9,500 kilometres away, in a rural corner of North Dakota. The Killdeer mountains in the western part of the state are rich in erionite, and they serve as the only nearby source of stone for surrounding Dunn County. When Ed Murphy, the state geologist, heard about the Turkish cancer villages five years ago, he grew concerned and launched an investigation that found erionite in gravel covering hundreds of kilometres of roads. It also turned up in driveways, car parks and even a playing field used by children. The North Dakota study eventually grew into a global collaboration including cancer biologists, geologists, epidemiologists, environmental scientists and physicians. And this week, the team is reporting some worrying results: that levels of exposure to erionite in North Dakota are the same as in some of the Turkish villages ravaged by mesothelioma.

The cancer hasn't yet shown itself in North Dakota, but mounting evidence suggests that large-scale clean-up efforts should commence immediately, says Michele Carbone, a mesothelioma expert at the

University of Hawaii in Honolulu who has worked in both North Dakota and the Turkish villages. "The reason that I find it exciting is that here we have a chance to do something," he says.

Carbone has been visiting Cappadocia since 1996, when he was invited by İzettin Bariş, a physician who at the time specialized in studying and treating mesothelioma at Hacettepe University in Ankara. Starting in the 1960s, Baris travelled the country, uncovering small clusters of the rare cancer - generally alongside local sources of asbestos. The microscopic, needle-like fibres of asbestos penetrate the lungs and get stuck in the surrounding mesothelial tissues, causing inflammation, scarring and, eventually, cancer. Villagers, says Bariş, had been unknowingly mixing the durable white mineral into the stucco on their buildings.

\title{
DEADLY FIBRES
}

In 1975, Bariş was called to help with a crisis in the village of Karain. The previous year, the town of just 604 adults had lost 11 to mesothelioma, a disease that usually affects only a few people per million. The epidemic had given the town an infamous reputation. Bariş wrote in 1978: "The saying goes that 'The peasant of Karain falls ill with pain in the chest and belly, the shoulder drops, and he dies."' But unlike everywhere else that Bariş had investigated, there was no asbestos to be found in Karain, nor in the nearby towns of Tuzköy and Sarıhıdır, which also had high rates of death due to mesothelioma. Bariş searched for a culprit, and in the early 1980s he found one, with the help of Frederick Pooley, a geolo-

D NATURE.COM For a slideshow showing more on erionite see: go.nature.com/7ce5jj gist at University College, Cardiff, UK. On the streets of the cancer villages and in the lungs of the mesothelioma patients, Bariş, Pooley and their collaborators found microscopic bits of erionite, which has fibrous qualities like those of absestos ${ }^{2}$.

Bariş's work gave the villages a somewhat 
unwelcome celebrity status among cancer researchers. In 1987, his studies and others led the International Agency for Research on Cancer in Lyon, France, part of the World Health Organization, to classify erionite as a group 1 carcinogen - of clear danger to humans. Some research suggests that the mineral might have even greater potential to cause cancer than asbestos.

Murphy had no idea of erionite's dangers in the 1980s, when it turned up in rocks that he collected during a survey of the Killdeer mountains. Twenty years later, he heard about the mineral's connection to cancer in Cappadocia and alerted state health officials. Together, they collected samples from the roads in Dunn County and found erionite in the gravel and dust. They notified the Environmental Protection Agency (EPA).

In October 2006, a team led by the EPA began to assess residents' exposure to erionite by collecting air samples while simulating everyday activities. The team raked car parks and followed vehicles that kicked up dust along the gravel roads. "Lo and behold, even though it was windy and rainy and snowing, we had exposures that were quite impressive," says Aubrey Miller, then a senior medical officer for the EPA in Denver, who led the team. The levels were below the regulatory limits for occupational asbestos exposure, but were high enough to raise concerns about community exposure, says Miller.

The data left many questions. The EPA has not established any guidelines for safe exposure to erionite and it was unclear whether the levels of exposure in North Dakota were the same as those that cause problems in Cappadocia, or even whether the erionite itself was the same. The group needed data from Turkey, so Miller contacted Carbone, who by this time was known as an expert on the cancer villages. "I convinced the EPA to come to Cappadocia and bring their expensive equipment and team," says Carbone.

\section{SERIOUS EXPOSURE}

Geologists, epidemiologists and environmental scientists travelled to Turkey to sample the air and compare the erionite with samples from North Dakota. The authors presented the results of these and other studies on 9 December at the Chicago Multidisciplinary Symposium in Thoracic Oncology in Illinois, and their findings paint a bleak picture for Dunn County and its 3,000 inhabitants. Erionite exposure levels in North Dakota are not quite as high as those in Tuzköy, Karain and Sarıhıdır, but they equal or exceed those in neighbouring Boyall, where $6.2 \%$ of all deaths are caused by mesothelioma. The structure and composition of the erionite from both regions is practically identical, and samples from each place cause mesothelioma-associated changes and inflammation in cell culture and mouse lungs.

Still, the human data are harder to interpret. Mesothelioma can appear 30 years or more after exposure to asbestos. Many of the roads in Dunn County have been around at least that long, but cancer records for the state have been spotty. North Dakota doesn't seem to have a higher incidence of the disease than is normal nationwide, so the scientists looked to see whether residents were exhibiting early warning signs. Researchers at the University of Cincinnati in Ohio collaborated with the North Dakota department of health to round up more than 30 individuals with high occupational exposure to erionite dust, including some who had worked in the quarries and on the crews that paved the roads. Murphy was also a subject.

The researchers studied the subjects' lungs using X-ray and high-resolution computed tomography scans. According to their report, released in October $^{3}$, the subjects showed unusual changes in their lung tissue at roughly eight times the rate seen in a study of similarly aged transportation workers, although these could have had many causes. More tellingly, two people had 'pleural plaques', essentially scarring in the lining of the chest cavity, consistent with exposure to mineral and man-made fibres.

For Miller, now a senior medical adviser at the National Institute for Environmental Health Services in Bethesda, Maryland, the similarities between erionite and asbestos are too great to ignore in Dunn County.
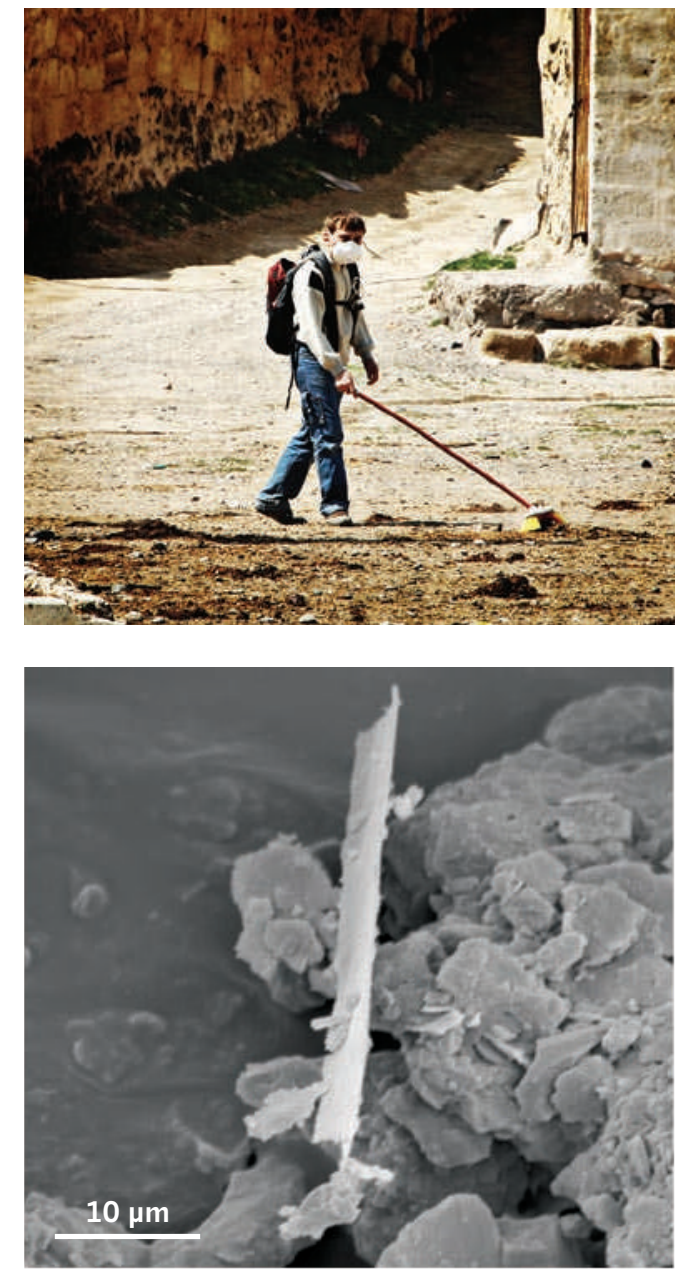

Top: Air-sampling in Turkey found dangerous levels of the carcinogenic mineral erionite. Bottom: Micrograph of an erionite fibre in road gravel from North Dakota. "Does it look like a duck? Does it quack like a duck? Does it have exposure?" he says.

The search is on to find out whether there are other areas in which people might be exposed to erionite, something that Carbone thinks is likely. Deposits of the mineral are known throughout western North America, Japan, New Zealand and parts of Europe. If researchers can identify populations at risk, they could help to reduce further exposure to erionite and monitor for signs of disease, says Carbone, who has been working with geologists to survey parts of Arizona, Nevada, Oregon, California and Idaho for the mineral.

In Turkey, his team is investigating whether genetic factors predispose some people more than others to developing mesothelioma after exposure to erionite or asbestos. The researchers are also looking for metabolites in the blood that might predict the onset of disease. Large-scale studies are set to begin next year, and Carbone says that such research could help in developing treatments and early-detection strategies. After decades of study, Turkish officials are now building new housing in some of the villages of Cappadocia, and residents are being moved - some of them with great reluctance. Meanwhile, officials in North Dakota are also making changes. Gravel mining in the area has tailed off, and most road work is done with stone from other areas. The playing field has been cleaned up, and talks are in progress about whether the roads can be paved over. But gravel containing erionite is still in use in some places, and all the scientists can do is advise. The EPA has no authority to regulate erionite, says Miller.

Given the lack of mesothelioma clusters in North Dakota, many residents there are not concerned about erionite, says Murphy. $\mathrm{He}$ frequently hears people say, "We've lived here for years. We're third generation or so, and no one has had a problem that we know of." In terms of his own health, Murphy found nothing too troubling in his recent scans. But with his record of exposure to erionite, he knows that he needs to keep monitoring his lungs. "I try not to dwell on it," he says. — SEE EDITORIAL P.868

Brendan Maher is a features editor for Nature.

1. Bariş, Y. İ. et al. Thorax 33, 181-192 (1978).

2. Sebastien, P., Gaudichet, A., Bignon, J. \& Baris, Y. I. Lab. Invest. 44, 420-425; (1981).

3. Radiographic Changes Associated with Exposure to Erionite in Road Gravel in North Dakota (US EPA, 2010); available at go.nature.com/pb5j7p. 